\title{
EFFECT OF STEM DIAMETER, MEDIA TYPE AND LIGHT INTENSITY ON THE GROWTH OF MEDICINAL PLANT OF SCREW TREE/KAYU ULES (Helicteres isora Linn.)
}

\author{
Dani Pamungkas*, Aziz Umroni and Nurhuda Adi Prasetyo \\ Research and Development of Environment and Forestry Institute of Kupang \\ Jl. Alfons Nisnoni No. 7 (Belakang) Airnona, Kota Raja, Kupang, Nusa Tenggara Timur
}

Received: 25 Januaury 2021, Revised: 5 August 2021, Accepted: 15 September 2021

\begin{abstract}
EFFECT OF STEM DIAMETER, MEDIA TYPE AND LIGHT INTENSITY ON THE GROWTH OF MEDICINAL PLANT OF SCREW TREE/KAYU ULES (Helicteres isora Linn.). Screw tree (Helicteres isora Linn.) known as kayu ules is a shrub species (Fam: Malvaceae) with $1.5-4 \mathrm{~m}$ in height and with multi-main trunks up to 9-12. In Indonesia, kayu ules has been used as a traditional medicine, known as jamu, and has been commercialized. In order to cultivate this species, vegetative propagation is likely promising compared to the generative propagation since seed viability is low and cannot be stored for long period. Nevertheless, there is a lack of information on which diameter classes, media types and light intensities would give the best result for vegetative propagation. This research aimed to obtain information on which diameter classes and media type suitable for kayu ules stem cutting propagation the light intensity degree for the growth of kayu ules seedlings. Three diameter classes and four media types were employed in a complete random design under the greenhouse environment. Three months old good quality vegetatively-propagated seedlings were transplanted under two light intensities (under transparent canopy and shading net). Result shows that considering diameter classes and media type in kayu ules stem cutting propagation, it had improved the survival of the stem cutting. Diameter class I was the best grown in media type 3 with $46.67 \pm 12.2 \%$ of survival rate, diameter class II was best grown in media type 2 with $38.67 \pm 11.6 \%$ of survival rate, whereas diameter class III was best grown in media type 4 with $52 \pm 6.9 \%$ of survival rate. The transplanted seedlings also grew significantly better under transparent canopy with higher light intensity. The distinctive features of screw tree under shading net were wider leaf area, higher specific leaf area and relative water content but it was lower in above ground dry biomass compared to the kayu ules under transparent canopy.
\end{abstract}

Keywords: Screw tree, traditional medicine, diameter class, media types, light intensity

PENGARUH DIAMTER BATANG, JENIS MEDIA, DAN INTENSITAS CAHAYA TERHADAP PERTUMBUHAN TANAMAN OBAT KAYU ULES (Helicteres isora Linn.). Tanaman kayu ules (Helicteres isora) merupakan jenis tumbuhan semak (Fam: Malvaceae) dengan tinggi antara 1,5-4 m dan memiliki cabang utama antara 9-12 batang. Tanaman ini telab lama digunakan sebagai jamu di Indonesia baik secara tradisional maupun komersial. Perbanyakan vegetatif memiliki tingkat kesuksesan lebih tinggi dibandingkan secara generatif karena viabilitas biji yang rendah dan tidak dapat disimpan dalam jangka waktu yang lama. Namun informasi mengenai kelas diameter stek, jenis media, dan intensitas cabaya yang dapat memberikan hasil terbaik masib kurang. Penelitian ini bertujuan untuk memperoleh informasi kelas diameter dan jenis media yang cocok untuk perbanyakan stek batang kayu ules dan seberapa besar intensitas cahaya akan memberikan hasil terbaik terbadap pertumbuban bibit kayu ules. Tiga kelas diameter dan empat jenis media disusun menggunakan desain rancangan acak lengkap di dalam rumah kaca. Setelah tiga bulan, bibit kayu ules yang tumbub terbaik kemudian dipindabkan dibawah dua intensitas cabaya (di bawab kanopi transparan dan paranet). Hasil penelitian menunjukean bahwa dengan memperbatikan faktor diameter kelas dan media pada perbanyakan stek batang kayu ules dapat meningkatkan keberbasilan stek. batang. Kelas diameter I memiliki persentase terbaik pada tipe media 3 (46,67 $\pm 12,2 \%)$, kelas diameter II memiliki persentase terbaik pada tipe media 2 (38,67 $\pm 11,6 \%)$, sedangkan kelas diameter III memiliki persentase terbaik pada tipe media 4 (52 \pm 6,9\%). Bibit yang telab dipindabkan tumbub lebih baik di bawah kanopi transparan dengan intensitas cahaya yang lebih tinggi. Perbedaan pertumbuhan tersebut terlihat bahwa tanaman kayu ules di bawah paranet memiliki luas daun besar, luas daun spesifik, dan kadar air relatif yang lebih tinggi,

*Corresponding author: dani.mungkas@gmail.com 
akan tetapi memiliki biomassa kering di atas permukaan tanah yang lebih rendah dibandingkan dengan tanaman kayu ules di bawah kanopi transparan.

Kata kunci: Kayu ules, obat tradisional, kelas diameter, jenis media, intensitas cahaya

\section{INTRODUCTION}

Medicinal plants have been widely used for centuries because of the medicinal properties which is believed to be delivering health benefits. Parts of the medicinal plants that can be effectively used to heal certain diseases vary depending on the species. For example, the medicinal benefit of some species is obtained from the bark, leaves, root, and fruits; meanwhile, from some species the benefits are obtained from the whole parts of the plants (Umair, Altaf, \& Abbasi, 2017). Medicinal plants has been part of Traditional Medicine (TM) in several countries in Asia. In India, according to the report of Deb et al. (2015), medicinal plants has an important role as a predominant rural health care system because this is the only health facility available for some rural areas of Manipur. In this report, for example, the medication of rural healer is able to formulate 949 formula for human illnesses.

In other region of East Asia such as China, TM has been the dominant part in the health care system since 5000 years ago. Now many clinical data show the efficacy and effectiveness of TM, and today the traditional medicine is an important part of the public health system in China (Yuan, Ma, Ye, \& Piao, 2016). Furthermore, traditional medicine is included in the formal education system in Japan, Korea and China (Park, Lee, Shin, Liu, Shang, Yamashita, \& Lim, 2012; Park, Huang, Sasaki, Ko, Park, \& Ko, 2016). Similar to countries of East Asia, until today traditional medicine has also been practiced for long time in Indonesia by the local healers that has various specifications (Husain \& Wahidah, 2018). At the industrial level, the demand of medicinal plants in Indonesia is abundant; in the form of raw materials $42 \%$ is derived from exploitation in the natural habitat to meet approximately 1,000 ton of demand annually (Pribadi, 2015). This high raw material demand for traditional medicine extracted from the nature would need to be equilibrated with the domestication effort of the plant.

Screw tree (Helicteres isora Linn., Fam: Malvaceae) or kayu ules is one medicinal plant that have been used in Indonesia, India Malaysia, Saudi Arabia, and China as mentioned in Ayurveda (Cunningham, Ingram, Brinckmann, \& Nesbitt, 2018; Dayal, Singh, Ojha, Mishra, 2015). In Indonesia, the fruit of kayu ules is one of the important material used in TM by local healers. At the industrial level, the fruit of kayu ules is imported from India to meet the demand, to meet the need of 4.5 ton/month of kayu ules fruit by the leading local industry in Java (Cunningham et al., 2018). Kayu ules has medicinal benefit that has been identified, several active compounds are contained in the fruit, bark, and stem prominently for diabetic therapy (Chandirasegaran, Elanchezhiyan, Ghosh, \& Sethupathy, 2016; Kumar, Sharma, Lemos, \& Shriram, 2013). It is also an effective anticancer media from the antioxidant compounds, diarrhea (Gayathri, Srinivasan, \& Saroja, 2010; Kumar et al., 2013) and antibacterial activity (Sabale et al., 2012).

Even though the research on kayu ules regarding its medicinal potential has been progressively undertaken domestication of the species is scarcely done. Ferdousi, Rahman, and Hassan (2014) have shown that generative propagation through seeds is not effective due to the very low survival, whilst the vegetative way appears to be a potential and the plant can grow reaching flowering season. Muthukumar, Kumar, and Rao (2017) add that 
the seeds of kayu ules is not suitable for long term storage. A recent study by Pamungkas, Siswadi, and Manurung (2019) has elucidated that kayu ules can be propagated through stem cutting, and the study has recommended several potential diameter classes of the stem cuttings; nevertheless, there is no information on how significant are the differences between the diameter classes. The study is also less information of media for the growth of kayn ules stem cutting whether under high or low light intensity.

Kayu ules can be found spreading from India to Southeast Asia, Australia and northern pacific. It is mostly found in hilly slope habitats (Basniwal et al., 2009). The predominant habitat of kayu ules found in India, for example, is dry forests where it grows as a sub-deciduous species upto 1.5-3.0 $\mathrm{m}$ in height (Kumar \& Singh, 2014). According to Cunningham et al. (2018), the natural habitat of kayu ules in Indonesia found in dry forests of West Timor and Sumba. The population of this plant is found to be distributed scatterly with relatively low density. Umroni, Pamungkas, Tanopo, and Manurung (2015) have reported that kayu ules grows in association with other species or neighbouring vegetation in the natural habitat of West Timor.

The neighbouring vegetation of kayu ules is varied from seedlings to tree level, such as Leucaena leucocephala (seedling), Psidium guajava (sapling), Timonius sericeus (pole), and Cassia siamea (tree). In the natural habitat, kayu ules showed differences of growth relating to the availability of light that is affecting the fruit quality (Pamungkas \& Siswadi, 2020). Fruit quality of kayu ules is reported to be low under shaded area compared to kayu ules that receives higher light intensity in terms of post-harvest fruit weight, dried-fruit weight, fruit water content, and fruit dimension. Fruit of kayu ules is not the only product that can be used. Stem bark, root, and leaves have also been reported to contain beneficial compound, potential for curing diseases (Chandirasegaran et al., 2016; Jain et al., 2014; Kumar \& Singh, 2014).
Considering the importance of kayu ules as a medicinal plant, this study, therefore, aimed to investigate which diameter classes and media were best for propagating kayu ules considering the availability of light. Previous study of Ferdousi et al. (2014) and Muthukumar et al. (2017) elucidated that kayu ules multiplication through seeds had faced some obstacles, includes low viability of the seeds. Previous study by Pamungkas et al. (2019) and Ferdousi et al. (2014) have shown that kayu ules is able to be propagated through stem, the present study was to enhance the method of propagation by considering the diameter classes, media use and light availability. The enhanced method of the present study had become a challenge because more attention should be paid on the diameter classes of the stem cutting, because some diameter classes would have better survival compared to others. The media use also had an impact on the survival of the kayu ules stem cutting. Light availability appeared to have big impact in the subsequent growth of the vegetatively-propagated kayu ules as reported by Pamungkas and Siswadi (2020).

\section{MATERIAL AND METHOD}

\section{A. Study Site}

The stem cutting materials of kayu ules were collected from its natural habitat located at Bosen Village, North Mollo District, South Central Timor (Timor Tengah Selatan/ TTS) Regency, East Nusa Tenggara (NTT), Indonesia (S 09'42'34,1" and E 124'18'03,5”). Geographically, the natural habitat's elevation was $\pm 691 \mathrm{~m}$ above sea level (m asl). Meanwhile, the experiment was undertaken at Oelsonbai nursery, Fatukoa, Kupang NTT with an elevation of $\pm 343 \mathrm{~m}$ asl. The experiment was carried out from March 2019 to February 2020.

\section{B. Research Description}

\section{Media and Stem Cutting Preparation}

In the natural habitat kayu ules was a multimain stem plant with between 9-12 stems from where the stem cutting material was derived 
for the experiment. The orthotrophic stem were taken from several kayu ules plants which were $2-3 \mathrm{~m}$ in height. The cuts were made using stem cutting scissors of $25 \mathrm{~cm}$ in length as recommended by Ferdousi et al. (2014) and sorted in 3 diameter classes, namely diameter class I (D1 5.86-7.61 mm), diameter class II (D2 7.62-9.37 mm), and diameter class III (D3 9.38$11.13 \mathrm{~mm}$ ) as recommended by Pamungkas et al. (2019). The collected stem cuttings were then put into plastic clip bag to avoid the evaporation of the stem. A commercial growth regulator (Atonik - containing Natrium paranitrogenol $3.0 \mathrm{~g} / \mathrm{L}$, Natrium orto-nitrofenol $2.0 \mathrm{~g} / \mathrm{L}$, Natrium 5-nitroguaiakol $1.0 \mathrm{~g} / \mathrm{L}$ and Natrium 2-4 dinitrofenol $0.5 \mathrm{~g} / \mathrm{L}$ ) was used for 30 minutes prior to stem cutting by soaking the base of the stem into $1 \%$ concentration of Atonik (10 ml/1000 $\mathrm{ml}$ of water).

Media for planting of stem cutting were made with five main materials, which were river sand, rice husk, half-composted rice husk, manure, and topsoil. The rice husk and half-composted rice husk were collected from local farmers around the nursery who were stacking the rice husk after harvesting. The half-composted rice husk was rice husk stacked by the local farmer under open environment for a long time and had visually changed its colour and structure but it was not fully composted. Both rice husk types were sterilized using heat sterilisation on steel pan before application. The medium materials were then mixed in four combination, namely media 1 [M1 rice husk: river sand (1:1)], media 2 [M2 half-composted rice husk: river sand (2:1)], media 3 [M3 topsoil : manure: halfcomposted rice husk: river sand (3:2:2:1)] and media 4 [M4 topsoil: half-composted rice husk: river sand (3:2:1)]. The media were filled into polybag of $7.5 \times 20 \mathrm{~cm}$ in size.

\section{Experimental Design}

Two main factors of diameter classes of stem cutting and media were arranged in completely randomized design (CRD). There were 24 treatment combinations. Each treatment combination was repeated 3 times, and each repetition used 25 stems; thus, 900 stem cuttings were used. The seedlings of stem cutting were stored inside plastic house to maintain the humidity. During the experiment, the maximum temperature in the plastic house was between $31.2-38.5^{\circ} \mathrm{C}$ and minimum temperature was between $19.4-23.8^{\circ} \mathrm{C}$. Meanwhile, the average relative humidity was $85,86 \%$. The seedlings were regularly watered once every two days to maintain the humidity of the media.

\section{Stem Cutting Transplantation}

After three months of vegetative propagation under the plastic house, the vegetatively-propagated seedlings were taken out of the plastic house for examining further growth by dividing it into two light intensities (under transparent canopy and shading net) in which each light condition used seedling with previous treatment combinations, diameter classes and media (called 'plant type'). The most healthy seedlings from the plastic house were transplanted into a polybag with $15 \times 30$ $\mathrm{cm}$ in size, and the media was the mixture of topsoil, manure and river sand (2:1:1) (v/v). The experiment was performed with split-plot design in which the light intensities were the whole plot, and plant types were the sub-plot. Each light intensity treatment used 12 plant types from the previous experiment. This was repeated three times with three seedlings at each repetition, thus 216 seedlings were used in total in this experiment. The comparison of light intensities is shown in Figure 1. These two light levels were measured at five spots under light treatment using light meter 'Krisbow' (KW06-288) over the seedlings.

\section{Plant Growth Measurement and Analysis}

\section{Growth Measurement}

Parameters measured at the plastic house were survival rate of the seedlings and the number of primordial shoots, these were measured every week. The further growth of kayu ules seedlings under two light intensities were measured for parameters of final-shoot length, diameter and increment. The shoot 
measurement was undertaken on purposivelyselected shoots by labelling one shoot for identification and were conducted every month. Shoot length increment was measured using the following equation (Lestari \& Nichols, 2017). $\left(\frac{l_{2}-l_{1}}{\Delta t}\right) m m$ month $^{-1}$

Shoot diameter increment was measured using the following equation (Lestari \& Nichols, 2017).

$\left(\frac{d_{2}-d_{1}}{\Delta t}\right) m m m o n t h^{-1}$

Remarks:

$l_{1}, d_{1}=$ the initial growth of length (l) and diameter (d) $1_{2}, d_{2}=$ the final growth of length (l) and diameter (d) $\Delta \mathrm{t}=$ the time between initial and final measurement.

\section{Leaf Area and Specific Leaf Area (SLA)}

The leaf area measurement was undertaken through the digital method described in O'neal et al. (2002) using computer software known as NIH Image software developed by National Institutes of Health (NIH). Three most expanded and healthiest leaves of kayu ules seedlings were collected from each treatment with different seedling. Sampled leaves were gently cleaned from dust using tissue paper, placed on A4 size scanner machine (Canon mx 397) along with ruler $(\mathrm{cm})$ for calibration of the pixel dimension. The output of the scanning was a jpeg file used for further analysis using NIH Image software. Afterwards, the sampled leaves were stored into a paper bag to obtain data of oven-dried leaves for leaf mass. SLA was calculated as described in Atwell et al. (1999) using the following equation:

Specific leaf area $=\frac{\text { Leaf area }}{\text { Leaf mass }}\left(\mathrm{cm}^{2} \mathrm{~g}^{-1}\right)$

\section{Relative Water Content (RWC) of leaf}

The data on RWC of leaf was obtained by measuring variables including fresh weight, turgid weight and dry weight of the leaves (Barr \& Weatherley, 1962; Mullan \& Pietragalla, 2012), which were then calculated using following the equation as described by Barr and Weatherley (1962).

$\left\{\frac{W-D W}{T W-D W}\right\} \times 100 \%$

\section{Remarks:}

$\mathrm{W}=$ leaf fresh weight

TW = leaf turgid weight

DW $=$ leaf dry weight

Three robust and healthy (Barr \& Weatherley, 1962; Mullan \& Pietragalla, 2012) leaves were collected and weighed to procure fresh weight (W). The leaves were then de-hydrated for 4 hours and quickly dried afterwards using

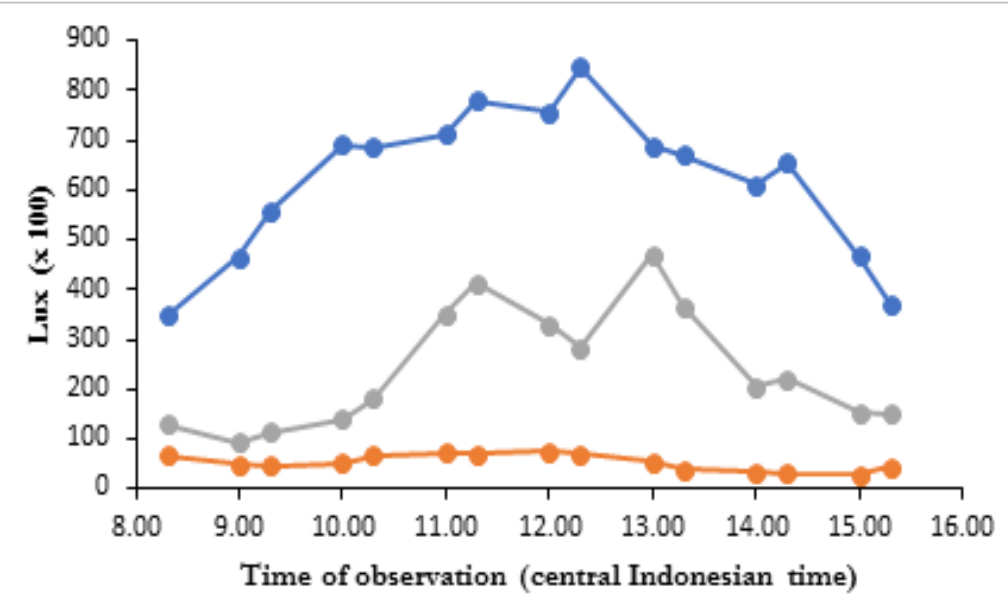

Figure 1. Comparison of daily changes in light intensities under open area (blue), transparent canopy (grey) and shading net (orange) 
tissue paper to be weighed to get turgid weight (TW), the leaves were then oven-dried at $90^{\circ}$ C for 24 hours (electrical oven "Memmert") to determine the dry weight of the leaves (DW).

\section{Above Ground Biomass}

The measurement of above-ground biomass was undertaken destructively. One plant with the most expanded and healthiest leaves was collected from each repetition at each treatment. Stems, leaves, and flowers were collected and stored in the paper bag before the drying process, which was done using an electrical oven (Memmert) at $100^{\circ} \mathrm{C}$ for 48 hours to obtain oven-dried biomass. Afterwards, the oven-dried biomass was weighed using an analytical balance.

\section{Statistical Analysis}

Data analysis, such as percentage were arcsine transformed before analyzing the variance (ANOVA). Any significant results were then analysed using the least significant difference (LSD) at $\alpha$ 0.05. Standard deviation between the replicates was also calculated.

\section{RESULT AND DISCUSSION}

\section{A. Survival Rate and Shoot Growth of the Kayu Ules Stem Cutting}

Treatment of diameter classes and media used in this experiment did not significantly differ $(p<0.05)$ on survival rate and the number of shoots according to analysis of variance. There was no interaction $(p<0.05)$ between the use of diameter classes and types of media. Even though there was no significance on the treatments, the survival rate of vegetativelypropagated kayu ules showed after 28 days a decreasing trend (Figure 2). The treatment of diameter classes showed a varied survival rate on different media. Diameter class I was best grown in media 3 with $46.67 \pm 12.2 \%$ survival rate, diameter class II was best grown in media 2 with $38.67 \pm 11.6 \%$ survival rate and diameter class III was best grown in media 4 with $52 \pm$ $6.9 \%$ survival rate.

Shoot production of vegetatively-propagated kayu ules showed varied performance in different media types, as presented in figure 3. Several shoots of diameter class I was best in media type 2 with $2.76 \pm 0.15$ shoots stem ${ }^{-1}$, meanwhile diameter class II showed better growth in media type 3 with $3.05 \pm 0.59$ shoots stem $^{-1}$, and diameter class III was best grown in media type 2 with $3.04 \pm 0.36$ shoots stem ${ }^{-1}$. Stem cuttings showed the lowest number of shoots with diameter class I that were grown in media type 4 with $2.18 \pm 0.31$ shoots stem $^{-1}$, stem cuttings with diameter class II was low on the number of shoots grown in media type 2 with $2.63 \pm$ 0.65 shoots stem $^{-1}$. Stem cuttings of diameter class III showed the lowest number of shoots that were grown in media type 1 with $2.77 \pm 0.31$ shoots stem ${ }^{-1}$.

This experiment had shown that diameter classes used as recommended by Pamungkas et al. (2019), had no significant $(\mathrm{p}<0.05)$ difference Pamungkas et al. (2019) when it is propagated, according to analysis of variance. In the study by Pamungkas et al. (2019), six diameter classes were retrieved from the treatment of stem cutting material sources, which were softwood, semi-hardwood and hardwood stem cuttings. These materials were then classified into six diameter classes at the end of the experiment but only three diameter classes appeared to be useful for propagation. Nevertheless, there was no information on whether these diameter classes would significantly differ $(\mathrm{p}<0.05)$ when it was propagated. Therefore, according to the present study as shown in Table 1 , it is indicated that treatments on diameter classes could be harnessed when the kayu ules propagation is made and could be an option for the cultivator depending on the most appropriate and the availability of the materials.

There were general patterns in primordial shoot production that higher diameter classes would give better growth than smaller diameter classes. These patterns have also been shown by a study of Hidayat et al. (2007) on Hopea odorata that stem cutting with higher diameter tended to have a more primordial shoot that was crucial to producing leaves for subsequent 

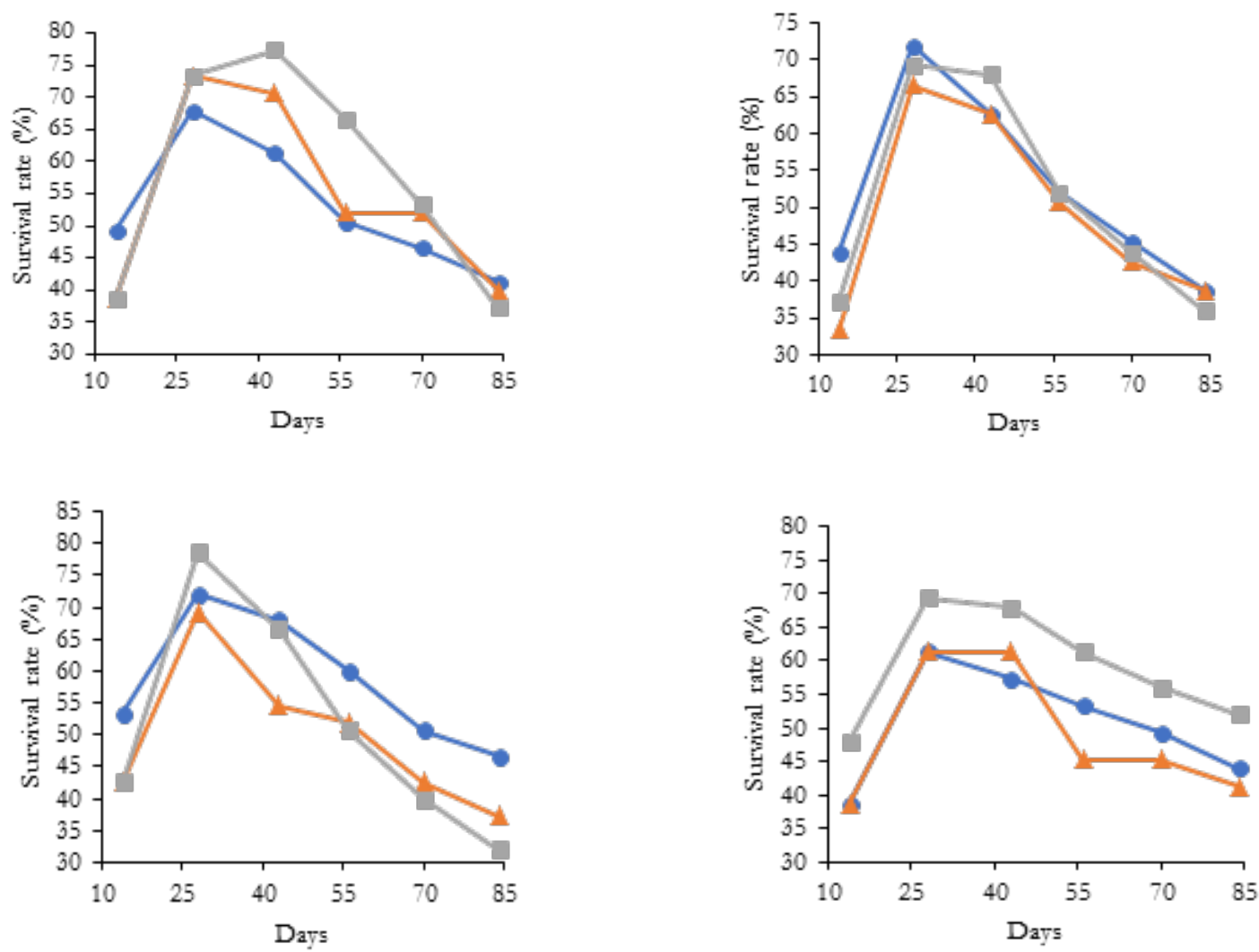

Remarks : blue line with circle is diameter class 1 , orange line with triangle is diameter class 2 , grey line with square is diameter class 3

Figure 2. Survival rates of three different diameter classes under different types of media

growth. The higher diameter of stem cutting that has higher survival could be affected by the availability of energy stored in the stem (Panjaitan et al., 2014).

Medium for growing plants is an important component as this will provide nutrient for plants to grow (Mukhtar, 2019). Even though media types in this study were not significant $(\mathrm{p}<0.05)$, the growth patterns can still be seen (Figure 3). For example, diameter class III of kayu ules exhibited to have even growth of primordial shoot at all media types, whilst diameter class I seemed unable to maintain the primordial shoot growth in media 3 and 4. Still, it could enhance the growth when the cuttings were grown in media 2. The insignificant $(p<0.05)$ difference of media types could indicate that the media used for kayu ules multiplication could be optional for the cultivator according to the availability of the materials, that is similar to the diameter classes. Furthermore, by choosing the least expensive materials for planting media due to insignificant $(\mathrm{p}<0.05)$ results, it could affect the cost of kayu ules propagation to be lower, and it is an advantage for the cultivator.

Sand in the mixed media used in this study was an important component, and it has been widely used because it is easy to be found and applied. However, sand as a single medium has high porosity that is difficult to retain water and could affect the medium humidity (Akinyele, 2010); hence a single use of sand for growing stem would not be benefitial. Singh et al. (2011) showed that sand only medium resulted in low success on the cuttings of Dalbergia sisoo branch stems compared to soil. Another study by Sardoei (2014) also elucidated that sand only medium used gave lower growth on 


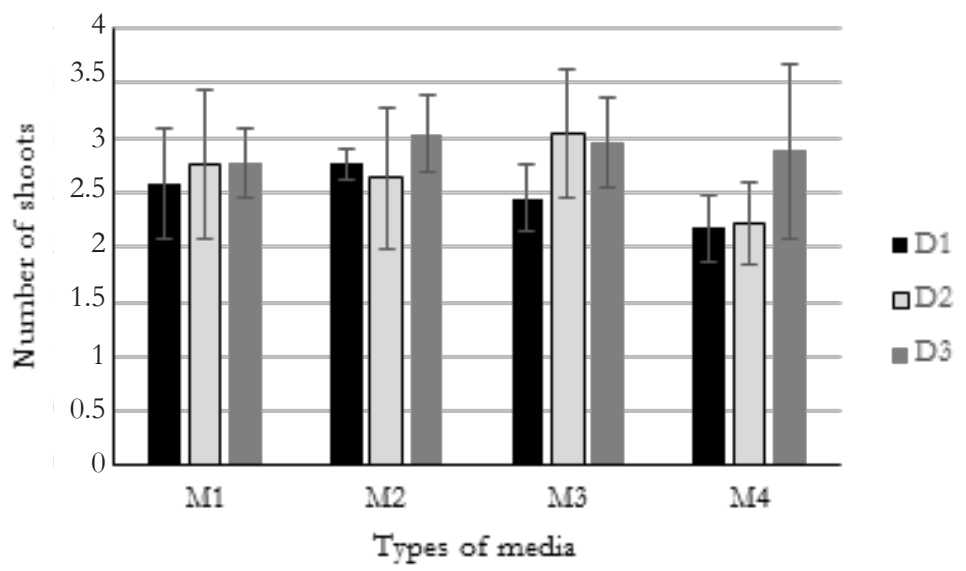

Remarks: D1 = diameter class 1, D2 = diameter class 2, D3 = diameter class 3; M1 = rice husk: river sand (1:1), M2 = half-composted rice husk $:$ river sand (2:1), M3 = topsoil $:$ manure $:$ half-composted rice husk : river sand $(3: 2: 2: 1)$, M4 = topsoil $:$ half-composted rice husk $:$ river sand $(3: 2: 1)$

Figure 3. A diagram of the average number of primordial shoots at three different diameter classes under different types of media

Psidium guajava under stem cutting propagation compared to those media which were mixed with other materials. Akinyele (2010) explained that mixing sand with other materials such as sawdust would preserve humidity and deliver adequate nutrients from decomposed sawdust; even topsoil could do it that sand cannot do, namely to give nutrient for plants.

\section{B. Shoot Length and Diameter Growth of Kayu Ules Seedlings Under Different Light Intensity}

The light intensities received by kayu ules seedling after being looked after for three months had significantly affected $(p<0.05)$ all growth parameters including final shoot length, final diameter, shoot length increment, and diameter increment. Meanwhile, the plant types (previous treatment combination) had significantly affected $(\mathrm{p}<0.05)$ only on final diameter and diameter increment. All parameter showed an interaction between the use of shade types and plant types.

Kayu ules seedlings maintained under shading net with lower light intensity generally declined in the final shoot length for most plant types compared to those under higher light intensity
(Figure 4). The highest decline of final shoot length could be seen in the plant type of M2D1, $55.9 \%$ or $88.78 \mathrm{~cm}$ of decline. This pattern was also shown in the final diameter (Figure 4) when kayu ules seedlings were subjected to shading net, which received low light intensity. The highest decrease in diameter was in M1D2 with $55 \%$ or $4.94 \mathrm{~mm}$ of decline. The use of shading net exposed to kayu ules seedlings generally decreased the length and diameter of the seedlings.

The shading net was inhibiting the increment of shoot length and diameter (Figure 4). The shoot length increments were generally lower for kayu ules seedlings under shading net; this was also shown on diameter increment. Meanwhile, with higher light intensity under the canopy, length and diameter increment of kayu ules showed to be vigorous. However, according to LSD value $\left(6.44 \mathrm{~cm} \mathrm{months}^{-1}\right.$ for length increment and $0.29 \mathrm{~mm}^{\text {month }}{ }^{-1}$ for diameter increment), it is not significant $(\mathrm{p}<0.05)$ at some plant types. The highest length increment under the canopy was in M2D1 with $19.36 \mathrm{~mm}$ months ${ }^{-1}$, whilst the highest length increment under shading net was in M2D2 with $13.83 \mathrm{~mm}$ month $^{-1}$. Meanwhile, on diameter increment, 

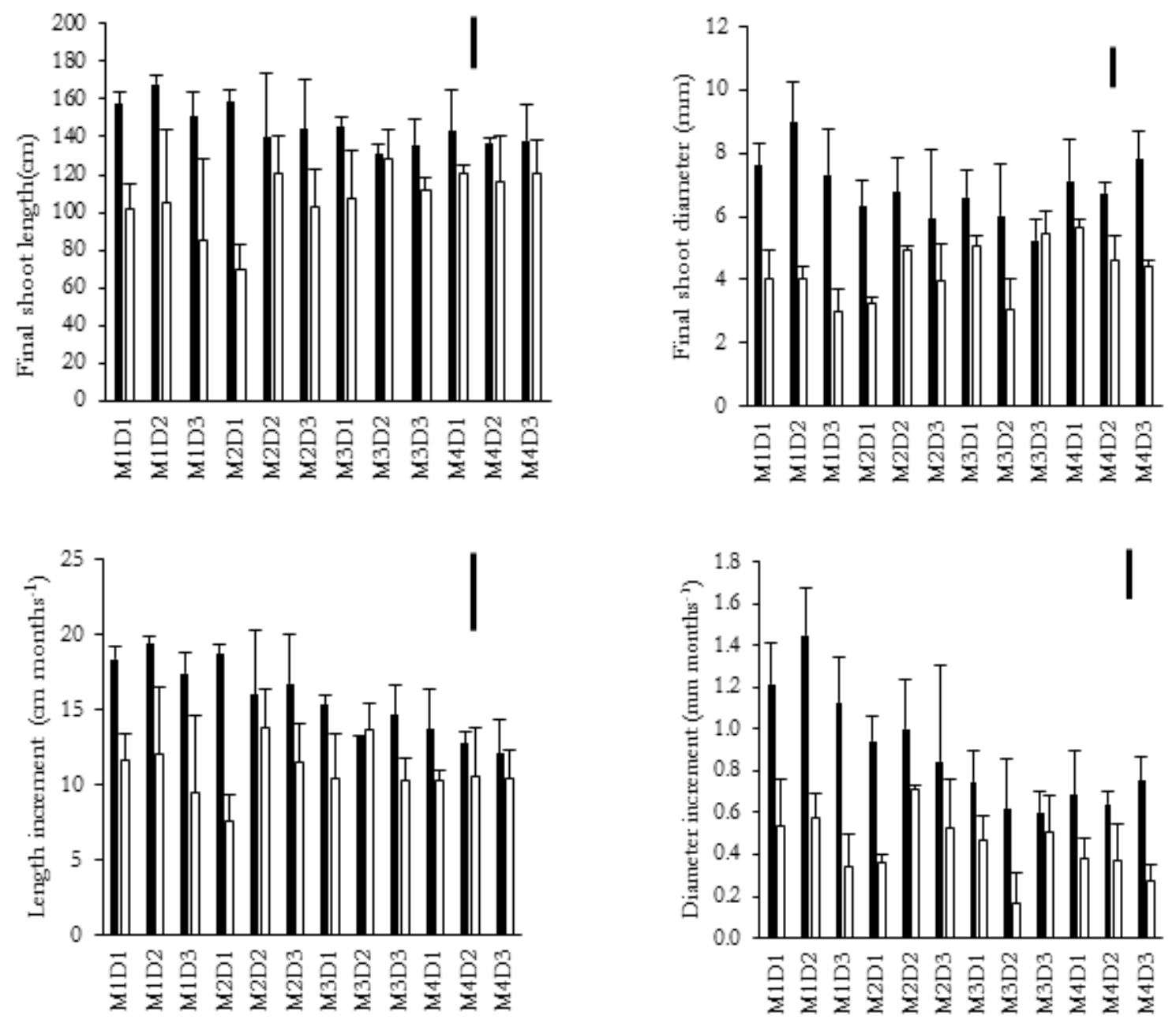

Remarks: Scale bar is the LSD $(\mathrm{p}<0.05)$ value indicating significant different, the gaps between treatments that are longer than scale bar mean significantly different. Black bars are under transparent canopy and white bars are under shading net. $\mathrm{M}=$ media, $\mathrm{D}=$ Diameter class

Figure 4. Final shoot length and diameter, shoot length and diameter increment of vegetatively propagated-kayu ules grown under canopy and shading net

the highest was under the canopy in M1D2 with $1.45 \mathrm{~mm} \mathrm{months}^{-1}$, whilst the highest diameter increment under shading net was in M2D2 with $0.71 \mathrm{~mm}^{\text {months }}{ }^{-1}$.

Kayu ules transplantation from the plastic house into two different light levels had exhibited significant $(\mathrm{p}<0.05)$ growth. The availability of light had given distinctive growth of kayu ules. The availability of light is an important factor for the plant to grow. This will influence plant growth parameters such as photosynthesis rate and transpiration that affect the plant's height and diameter (Zervoudakis et al., 2012; Fan et al., 2013). In this study, kayu ules seedlings were generally showing better growth under a higher light intensity of transparent canopy (Figure 4). Under transparent canopy kayu ules seedlings could reach higher height and larger diameter than under shading net. Kim et al. (2016) Kim et al. (2016) showed that Larix kaempferi in the field experiment produced better height and diameter in a thinned plot with $40 \%$ of thinning compared to without thinning or control. According to this study, the thinning applied on Larix kaempferi at the thinned area allowed the trees to intercept more light as there was less 
competition between neighbouring trees; hence there was adequate light for growing.

Furthermore, even though the growth of kayn ules under the shading net had been inhibited, there was no indication that the kayu ules seedling showed stressed growth under shading net, indicating that kayu ules could be a shading tolerant species. This study was in agreement with the study of kayu ules in the natural habitat by Pamungkas and Siswadi (2020). Kayu ules in natural habitat was found in low light intensity under tree shade; nevertheless, they were still able to grow and produce fruit although of low quality compared to those which received higher light intensity.

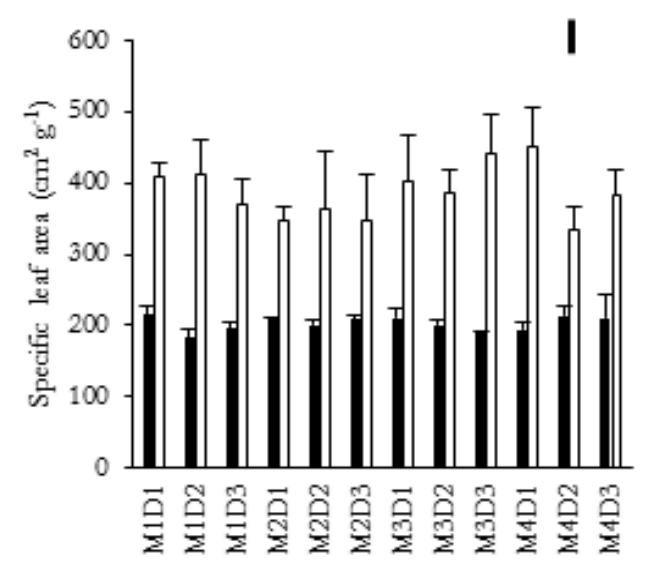

A. Specific Leaf Area (SLA)

\section{Leaf Traits Under Different Light Intensity}

Specific Leaf Area (SLA) of kayu ules seedling grown under the transparent canopy was significantly lower $(\mathrm{p}<0.05)$ than kayu ules grown under shading net according to LSD value of $59.09 \mathrm{~cm}^{2} \mathrm{~g}^{-1} \quad(\mathrm{p}<0.05)$ (Figure 5). This trend also appeared on the leaf area, with broader leaves under shading net. The highest SLA of kayu ules seedling grown under the canopy was in M1D1 with $214.88 \mathrm{~cm}^{2} \mathrm{~g}^{-1}$, and the lowest SLA was in M1D2 with $183 \mathrm{~cm}^{2}$ $\mathrm{g}^{-1}$. Meanwhile, the highest SLA of kayn ules seedling grown under shading net was in M4D1 with $452.12 \mathrm{~cm}^{1} \mathrm{~g}^{-1}$, and the lowest SLA of kayu ules seedling was in M4D2 with $335.97 \mathrm{~cm}^{2} \mathrm{~g}^{-1}$.

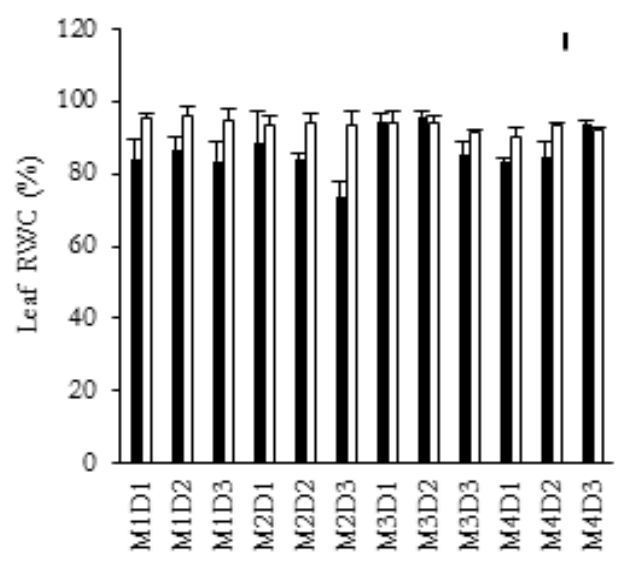

B. Leaf Area

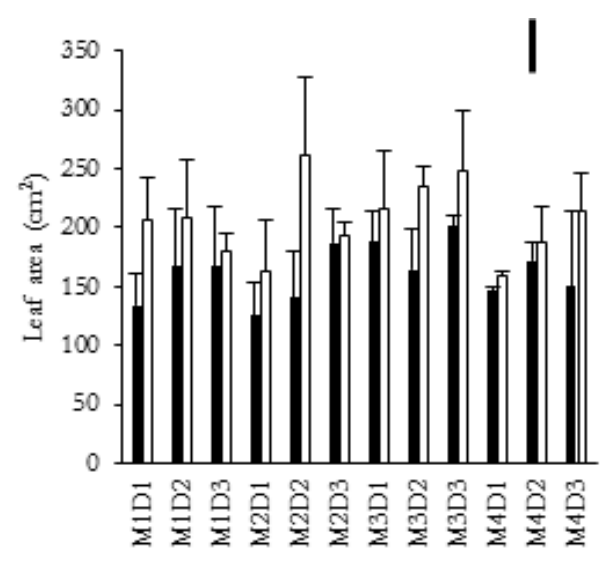

C. Leaf of Relative Water Content (WRC)

Remarks: Scale bar is the LSD $(p<0.05)$ value indicating significant different, the gaps between treatments that are longer than scale bar mean significantly different. Black bars are under transparent canopy and white bars are under shading net. $\mathrm{M}=$ media, $\mathrm{D}=$ Diameter class

Figure 5. SLA, leaf area, leaf RWC of vegetatively propagated-kayu ules seedlings grown under canopy and shading net 
These results agreed with the study of Fan et al. (2013) on tomato species that deficit of light intensity would have high SLA. These results could indicate that $H$. isora has morphological plasticity under lower light intensity. According to Aysajan and Qingjun (2018), morphological plasticity is the key to the plant adaptation to harsh environment. This environment would have a variation on climatic, elevation and other variables that could shape the plants' growth, affecting the plant's performance.

The increasing SLA in shaded plants had also been reported by Perrin and Mitchell (2013) on Taxus baccata in which the plants maintained under heavy shade would have higher SLA, as well as broader leaf area for shaded plants, compared to those of higher light intensity plants, as seen in Table 5. A study by Dai et al. (2009) on Tetrastigma hemsleyanum had also reported a similar pattern. The leaf morphology of the species had a larger leaf area when shaded compared to leaves with higher light level. Colour of leaves subjected under lower light intensity exhibited greener leaf than those under higher light level. Based on Zervoudakis et al. (2012) study, greener leaf indicated changes in photosynthetic pigments, higher in shaded plants. Higher photosynthetic pigments had physiologically higher chlorophyll (chl) a and b, and total chl content, conversely, the yellowish leaf exposed under full sunlight had lower chl a and b, and total chl content. According to Puglielli et al. (2017), higher SLA of plants also indicated thinner leaf of plants. Furthermore, higher SLA might reflect that kayu ules seedling grown under shading net were probably not able to effectively use larger leaf area to yield dry leaf biomass per gram, or kayu ules seedlings grown with higher light intensity under the transparent canopy were able to produce dry leaf mass per gram with lower leaf area compared to those grown under shading net.

RWC of leaf has been a common and an important parameter used to measure the physiological metabolism about biomass productivity and photosynthesis. In general, plant grown under a well-watered environment would have better growth than those grown under drought conditions (Vardharajula et al., 2011). Nevertheless, light intensity appears to affect the relative water content (RWC) of the leaf of kayu ules in this study. The RWC of kayu ules seedling was generally significantly affected $(p<0.05)$ by higher light level under transparent canopy compared to kayu ules seedling grown under shading net according to LSD value of $5.8 \%(\mathrm{p}<0.05)$ (Figure 5). The highest RWC of leaf of kayu ules seedling grown under the transparent canopy was on seedling M3D2 with $95.8 \%$, and the lowest RWC of leaf was on seedling M2D3 with $73.71 \%$. Meanwhile, the highest RWC of leaf of kayu ules seedling grown under shading net was on seedling M1D2 with $95.83 \%$, whilst the lowest RWC of leaf was on seedling M3D3 with 91.31\%.

\section{Biomass Allocation of Stem Cutting Seedling of Kayu Ules}

Above ground dried biomass was significantly affected $(\mathrm{p}<0.05)$ by the different light intensity levels under shading net and transparent canopy (Figure 6). The kayu ules seedlings maintained under the transparent canopy clearly had higher above ground dried biomass and inhibited when those were grown under shading net. The highest above ground dried biomass under the transparent canopy was reached by seedling M2D1 with $161.78 \mathrm{~g}$ plant $^{-1}$, whilst the lightest dried biomass was on M3D2 with $92.98 \mathrm{~g}$ plant $^{-1}$. The kayu ules seedling grown under shading net had the highest dried biomass on seedling M3D2 with 35.42 g plant $^{-1}$, and the lowest above-ground dried biomass was on seedling M2D1 with $16.70 \mathrm{~g}_{\text {plant }}{ }^{-1}$.

High dry biomass resulting from plants grown under and receiving higher light intensity than lower light intensity has been reported by Semchenko et al. (2012). Following the present study, kayu ules seedlings received higher light intensity under a transparent canopy had significantly higher $(\mathrm{p}<0.05)$ above-ground biomass. Muneer et al. (2014) working on Lactuca sativa had also reported that light intensity is an 


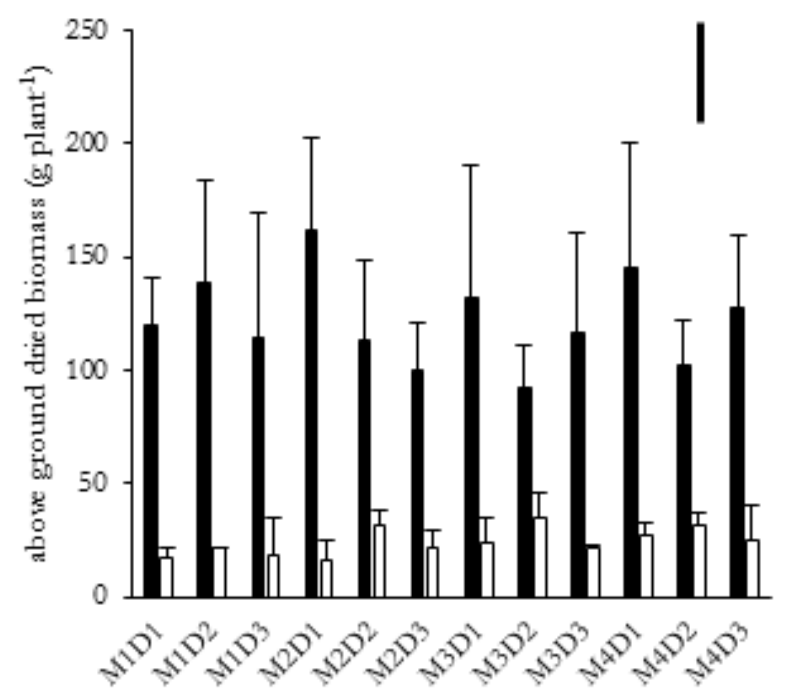

Remarks: Scale bar is the LSD $(p<0.05)$ value indicating significant different, the gaps between treatments that are longer than scale bar mean significantly different. Black bars are under transparent canopy and white bars are under shading net. $\mathrm{M}=$ media, $\mathrm{D}=$ Diameter class

Figure 6. Above ground dried biomass of vegetatively propagated-kayu ules seedlings grown under canopy and shading net

important environmental component for plant growth, even at different types of the light spectrum. His experiment reported that the higher light intensity in any light spectra; red, blue and green, resulted in higher plant biomass, especially on the dry weight of roots and leaves. Moreover, in the case of a growing environment that is not fully supporting plant growth, the light intensity remains to substantially affect the growth. For example, a study of Mielke and Schaffer $(2009,2010)$ reported that a shrub species of Eugenia uniflora was sampled to see whether the waterlogging environment affects the growth of Eugenia uniflora or not. The results showed that in spite of being periodically under waterlogged condition, Eugenia uniflora still showed ability to grow better under high light intensity.

\section{CONCLUSION}

Kayu ules can be propagated through stem cutting by using varied diameter classes in different types of media. This method had increased the survival of stem cutting of kayu ules compared to previously-done stem cutting method. Even though diameter class and media type treatments were not significant, diameter class III with the combination of media 4 have delivered to be the best result for kayu ules propagation through stem cutting with $52 \%$ survival rate. Under different light intensities, seedling growth of kayu ules were distinctively different. Kayu ules seedlings grown under the transparent canopy with higher light intensity had higher height and diameter on the final increment than those grown under shading net. Biomass production is also higher for kayu ules seedlings that are maintained under higher intensity. Therefore, it is suggested that higher light intensity under transparent canopy would result in optimum growth of kayu ules seedling through stem cutting.

\section{ACKNOWLEDGEMENT}

We thank the International Centre for Research in Agroforestry (ICRAF) and Research and Development Environment and Forestry Institute of Kupang in Kupang East Nusa Tenggara under the Ministry of Environment and Forestry for this research. We also thank 
Obed Meto, Lemuel Toto, Ibrahim Toto, and Oktofianus Tanopo to collect the stem cutting from the natural habitat at Bosen village and preparing the experiment materials at Oelsonbai Nursery.

\section{REFERENCES}

Akinyele, A. O. (2010). Effects of growth hormones, rooting media and leaf size on juvenile stem cuttings of Buchbolzia coriacea Engler. Annals of Forest Research, 53(2), 127 133. http://afrjournal.org/index.php/afr/ article/view/105.

Atwell, B. J., Kriedemann, P. E., \& Turnbull, C. G. N. (1999). Plants in action: Adaptation in nature, performance in cultivation. Australia: Macmillan Education.

Aysajan, A., \& Qingjun, L. (2018). Morphological plasticity and adaptation level of distylous Primula nivalis in a heterogeneous alpine environment. Plant Diversity, 40(6), 284-291. doi://10.1016/i.pld.2018.11.003.

Barr, H. D., \& Weatherley, P. E. (1962). A reexamination of the relative turgidity technique for estimating water deficit in leaves. Australian Journal of Biological Sciences, 15,413-428.

Basniwal, P. K., Suthar, M., Rathore, G. S., Gupta, R., Kumar, V., Pareek, A., \& Jain, D. (2009). In-vitro antioxidant activity of hot aqueous extract of Helicteres isora Linn. fruits. Natural Product Radiance, 8(5), 483-487. http://nopr. niscair.res.in/handle/123456789/6344.

Chandirasegaran, G., Elanchezhiyan, C., Ghosh, K., \& Sethupathy, S. (2016). Determination of antidiabetic compounds from Helicteres isora fruits by oral glucose tolerance test. Journal of Applied Pharmaceutical Science, 6(02), 172-174.

Cunningham, A. B., Ingram, W., Brinckmann, J. A., \& Nesbitt, M. (2018). Twists, turns and trade: A new look at the Indian screw tree (Helicteres isora). Journal of Ethnopharmacology, 225, 128 135.

Dai, Y., Shen, Z., Liu, Y., Wang, L., Hannaway, D., \& Lu, H. (2009). Effects of shade treatments on the photosynthetic capacity, chlorophyll fluorescence, and chlorophyll content of Tetrastigma hemsleyanum Diels et Gilg. Environmental and Experimental Botany, 65(2-3), 177-182. doi://10.1016/j. envexpbot.2008.12.008.
Dayal, R., Singh, A., Ojha, R. P., \& Mishra, K. P. (2015). Possible therapeutic potential of Helicteres isora (L.) and it's mechanism of action in diseases. Journal of Medicinal Plant Studies, 3(2), 95-100.

Deb, L., Laishram, S., Khumukcham, N., Ningthoukhongjam, D., Nameirakpam, S. S., Dey, A., Moirangthem, D. S., Talukdar, N. C., \& Ningthoukhongjam, T. R. (2015). Past, present and perspectives of manipur traditional medicine: A major health care system available for rural population in the North-East India. Journal of Ethnopharmacology, 169(September), 387-400. doi://10.1016/j. jep.2014.12.074.

Fan, X.-X., Xu, Z.-G., Liu, X.-Y., Tang, C.-M., Wang, L.-W., \& Han, X. (2013). Effects of light intensity on the growth and leaf development of young tomato plants grown under a combination of red and blue light. Scientia Horticulturae, 153, 50-55.

Ferdousi, A., Rahman, M. O., \& Hassan, M. A. (2014). Seed germination behaviour of six medicinal plants from Bangladesh. Bangladesh Journal of Plant Taxonomy, 21(1), 71-76.

Gayathri, P., S, G. D., Srinivasan, S., \& Saroja, S. (2010). Screening and quantitation of phytochemicals and nutritional components of the fruit and bark of Helicteres isora. Hygeia Journal for Drugs and Medicines, 2(1), 57-62.

Hidayat, A., Hendalastuti, H., \& Nurohman, E. (2007). Pengaruh ukuran diameter stek batang Hopea odorata Roxb. dari kebun pangkas terhadap kemampuan bertunas, berakar, dan daya hidupnya. Jurnal Penelitian Hutan dan Konservasi Alam, 4(1), 1-12.

Husain, F., \& Wahidah, B. F. (2018). Medicine from nature: Identification of medicinal plants used by belian (Sasakese indigenous healer) in traditional medicine in Lombok, West Nusa Tenggara, Indonesia. AIP Conference Proceedings, 2019(2018). doi://10.1063/1.5061896.

Jain, A., Ranade, R., Pritam, P., Joshi, N., Vavilala, S. L., \& Jain, A. (2014). A comparative study of antioxidant activity, total phenolic and flavonoid contents in different parts of Helicteres isora L. American Journal of Life Sciences, 2(5), 292. doi://10.11648/j.ajls.20140205.17.

Kim, M., Lee, W.-K., Kim, Y.-S., Lim, C.-H., Song, C., Park, T., Son, Y., \& Son, Y.-M. (2016). Impact of thinning intensity on the diameter and height growth of Larix kaempferi stands in central Korea. Forest Science and Technology, 12(2), 77-87. 
Kumar, N., \& Singh, A. K. (2014). Plant profile, phytochemistry and pharmacology of avartani (Helicteres isora Linn.): A review. Asian Pacific Journal of Tropical Biomedicine, 4, S22-S26.

Kumar, V., Sharma, M., Lemos, M., \& Shriram, V. (2013). Efficacy of Helicteres isora L. against free radicals, lipid peroxidation, protein oxidation and DNA damage. Journal of Pharmacy Research, 6(6), 620-625. doi://10.1016/j. jopr.2013.05.017.

Lestari, D. P., \& Nichols, J. D. (2017). Seedlings of subtropical rainforest species from similar successional guild show different photosynthetic and morphological responses to varying light levels. Tree Physiology, 37(2), 186-198. doi://10.1093/treephys/tpw088.

Mielke, M. S., \& Schaffer, B. (2009). Photosynthetic and growth responses of Eugenia uniflora L. seedlings to soil flooding and light intensity. Environmental and Experimental Botany, 68(2), 113-121.

Mukhtar, R. B. (2019). Effect of rooting media and hormone concentrations on vegetative propagation of Balanites aegyptiaca. Journal of Forestry Research, 30(1), 73-76. doi://10.1007/ s11676-018-0622-9.

Mullan, D., \& Pietragalla, J. (2012). Leaf relative water content. Physiological breeding II: A field guide to wheat phenotyping. Mexico: CIMMYT, 25-27.

Muneer, S., Kim, E. J., Park, J. S., \& Lee, J. H. (2014). Influence of green, red and blue light emitting diodes on multiprotein complex proteins and photosynthetic activity under different light intensities in lettuce leaves (Lactuca sativa L.). International Journal of Molecular Sciences, 15(3), 4657-4670.

Muthukumar, M., Kumar, T. S., \& Rao, M. V. (2017). Phenology and seed germination of the indian screw tree Helicteres isora L.(Malvales: Malvaceae). Journal of Threatened Taxa, 9(12), 11040-11044.

O'neal, M. E., Landis, D. A., \& Isaacs, R. (2002). An inexpensive, accurate method for measuring leaf area and defoliation through digital image analysis. Journal of Economic Entomology, 95(6), 1190-1194.

Pamungkas, D., \& Siswadi. (2020). Pengaruh naungan pohon dan teknik pemangkasan cabang terhadap produktivitas buah tanaman kayu ules (Helicteres isora Linn.) di habitat alaminya. Jurnal Wasian, 7(2), 73-86. doi://10.20886/ jwas.v7i2.5617.

Pamungkas, D., Siswadi, S., \& Manurung, G. E. S. (2019). Studi propagasi vegetatif tanaman obat kayu ules (Helicteres isora Linn.) melalui stek batang. Jurnal Penelitian Kehutanan Faloak, 3(1), 29-42. doi://10.20886/jpkf.2019.3.1.2942.

Panjaitan, H., Richi, L., Ginting, J., \& Haryati, H. (2014). Respons pertumbuhan berbagai ukuran diameter batang stek bugenvil (Bougainvillea spectabilis Willd.) terhadap pemberian zat pengatur tumbuh. Jurnal Agroekoteknologi Universitas Sumatera Utara, 2(4), 1384-1390.

Park, H. L., Lee, H. S., Shin, B. C., Liu, J. P., Shang, Q., Yamashita, H., \& Lim, B. (2012). Traditional medicine in China, Korea, and Japan: A brief introduction and comparison. Evidence-Based Complementary and Alternative Medicine, 2012. doi://10.1155/2012/429103

Park, Y. L., Huang, C. W., Sasaki, Y., Ko, Y., Park, S., \& Ko, S. G. (2016). Comparative study on the education system of traditional medicine in China, Japan, Korea, and Taiwan. Explore: The Journal of Science and Healing, 12(5), 375-383. doi://10.1016/j.explore.2016.06.004.

Perrin, P. M., \& Mitchell, F. J. G. (2013). Effects of shade on growth, biomass allocation and leaf morphology in european yew (Taxus baccata L.). European Journal of Forest Research, 132(2), 211-218.

Pribadi, E. R. (2015). Pasokan dan permintaan tanaman obat Indonesia serta arah penelitian dan pengembangannya. Perspektif, 8(1), 52-64.

Puglielli, G., Varone, L., Gratani, L., \& Catoni, R. (2017). Specific leaf area variations drive acclimation of Cistus salvifolius in different light environments. Photosynthetica, 55(1), 31-40.

Sabale, P. M., Grampurohit, N. D., Banerjee, Subir, K., Gaikwad, D. D., Gadhave, M. V, \& Name, B. (2012). Recent advances on the phytochemical and pharmacological profile of plant Helicteres isora Linn. International Research Journal of Pharmacy, 3(4), 14-17.

Sardoei, A. S. (2014). Effect of different media of cuttings on rooting of guava (Psidium guajava L.). European Journal of Experimental Biology, 4(2), 88-92.

Semchenko, M., Lepik, M., Götzenberger, L., \& Zobel, K. (2012). Positive effect of shade on plant growth: amelioration of stress or active regulation of growth rate? Journal of Ecology, 100(2), 459-466.

Singh, B., Yadav, R., \& Bhatt, B. P. (2011). Effects of mother tree ages, different rooting mediums, light conditions and auxin treatments on rooting behaviour of Dalbergia sissoo branch 
cuttings. Journal of Forestry Research, 22(1), 5357. doi://10.1007/s11676-011-0125-4.

Umair, M., Altaf, M., \& Abbasi, A. M. (2017). An ethnobotanical survey of indigenous medicinal plants in Hafizabad District, Punjab-Pakistan. PLOS ONE, 12(6), e0177912. doi://10.1371/ journal.pone.0177912.

Umroni, A., Pamungkas, D., Tanopo, O., \& Manurung, G. E. S. (2015). Aspek ekologi kayu ules (Helicteres isora L.) sebagai tanaman obat di Desa Bosen: Penyangga Cagar Alam Mutis Kabupaten Timor Tengah Selatan. Seminar Nasional Biodiversitas Savana Nusa Tenggara, 45-57.

Vardharajula, S., Zulfikar Ali, S., Grover, M., Reddy, G., \& Bandi, V. (2011). Drought-tolerant plant growth promoting Bacillus spp.: Effect on growth, osmolytes, and antioxidant status of maize under drought stress. Journal of Plant Interactions, 6(1), 1-14.
Yuan, H., Ma, Q., Ye, L., \& Piao, G. (2016). The traditional medicine and modern medicine from natural products. Molecules, 21(5). doi://10.3390/molecules21050559.

Zervoudakis, G., Salahas, G., Kaspiris, G., \& Konstantopoulou, E. (2012). Influence of light intensity on growth and physiological characteristics of common sage (Salvia officinalis L.). Brazilian Archives of Biology and Technology, 55(1), 89-95. doi://10.1590/ S1516-89132012000100011. 